\title{
Monetary and Financial Statistics is a Major Tool for Analysis of an Economy: Evidence from Pakistan
}

\author{
Azam Ali
}

\begin{abstract}
Proper dissemination and utilization of statistics is a basic requirement for high transparency in financial policies and efficient operation of financial markets, which have long been advocated by international organizations and central bank watchers (Hanke and Morgenstern 2001; Hanke; 2002). State Bank of Pakistan is playing a vital role in disseminating useful and important information in the form of monetary and financial statistics. It is observed that the public/researchers face difficulties in understanding the proper utilization of monetary and financial statistics in the analyses of their country's economy. This paper introduces the application technique of Monetary and Financial Statistics (MFS) in Pakistan under a theoretically sound framework. Findings discover how public/researchers can easily access the information available at web-sites of Financial Institutions. This paper also attempts, to explain the unique linkages of the monetary sector to the real sector economy.
\end{abstract}

Keywords: MFS, Pakistan, real sector, monetary sector.

\section{Introduction}

Money as the core studies in monetary economics has a high degree of theoretical and practical complexities as disguised by simple and even misleading surface appearances. Financial statistics include financial assets and liabilities of the entire economy that needs their deep understanding and vast knowledge for the analyses of any relevant field of study. It is observed that the public/researchers generally face difficulties in understanding thoroughly the practical application of monetary and financial statistics to analyze the economy of their country.

MFS not only indicate the aggregate level of economic activity, but also help promote transparency in Central-Bank policy and financial market operation. A thorough understanding of macroeconomic developments inevitably requires the consideration of monetary elements in view of the intrinsic link between the real sector and the monetary sector.

The monetary and financial statistics (MFS) of Pakistan, which are the scientific medium to indicate monetary phenomena and regularly released by the State Bank of Pakistan (SBP), are orderly presented. SBP is regularly compiling monetary and financial statistics which indicates the aggregate level of economic activity and promotes transparency in central bank policy and financial market operations.

Azam Ali is a Ph.D. student at SZABIST, Karachi and a Junior Joint Director, S \& DW Department, State Bank of Pakistan, Karachi, azam.ali@sbp.org.pk

Journal of Independent Studies and Research - MSSE

Volume 9

Number 2

July 2011 49 
The global need for monetary and financial statistics that are accurate, comprehensive, comparable across countries, and widely available on a timely basis has been understood by modern occurrences of instability in financial markets, ranging from the Asian debt cri sis of the 1990s to the recent strains in loan and securities markets in the world's most complex financial centers. Public/researchers generally face difficulties in understanding thoroughly the practical application of monetary and financial statistics to analyze the economy of their country, notwithstanding our intrinsically high sensitivity to money as the standard of income and expenditure.

The paper introduces the application techniques of Monetary and Financial Statistics (MFS) in Pakistan under a theoretically sound framework. It presents a sound statistical framework to enable stakeholders/ researchers and general public to utilize our Monetary and Financial Statistics, which is available on accessible web-sites of the financial institutions. A thorough understanding of macroeconomic developments inevitably requires the consideration of monetary elements in view of the intrinsic link between the real sector and the monetary sector. The study also explains the unique linkages of the monetary sector to the real sector economy with the help of few examples and relevant case studies. Findings discover how public/researchers can easily access the information available at web-sites of Financial Institutions.

\subsection{Background of the Study}

The monetary and financial statistics (MFS) of Pakistan, which are the scientific medium to indicate monetary phenomena and regularly released by the State Bank of Pakistan (SBP), are orderly presented. Proper dissemination and utilization of statistics is a basic requirement for high transparency in financial policies and efficient operation of financial markets, which have long been advocated by international organizations and central bank watchers (Hanke and Morgenstern 2001; Hanke; 2002). Public/researchers generally face difficulties in understanding thoroughly the practical application of monetary and financial statistics to analyze the economy of their country, notwithstanding our intrinsically high sensitivity to money as the standard of income and expenditure. Availability of tons of information in the form of monetary and financial statistics in hard form and in the soft form on the websites of financial institutions and central bank can help prepare valued papers which may be utilized by the scholars and policy makers in formulation of short-term and long-term plans. It is therefore our purpose, through organized introduction and plain explanation, to enhance a broader public utilization of the economically meaningful statistical resources.

\subsection{Problem Statement}

Like India, Sri Lanka and Macao, Pakistan has also implemented MFSM 2000 and preparing monetary and financial statistics on monthly basis. State Bank of Pakistan, the central bank of the country, is regularly compiling monetary and financial statistics which indicates the aggregate level of economic activity and promotes transparency in central bank policy and financial market operations. Researchers and general public are unaware of their access to treasure of data available on these web-sites. They do not know how to utilize this information in analyzing economy. This study sets out to address this deficiency of researchers and general public. 


\subsection{Study objectives}

Objective of our study is to present a sound statistical framework to enable stakeholders/ researchers and general public to utilize our Monetary and Financial Statistics, is available on accessible web-sites of the financial institutions. We discuss the means and ways to describe, how the linkages of monetary sector with the real sector can be helpful in analyzing the economy of a country.

\subsection{Research Methodology}

The research is qualitative in nature. For the purpose of analysis, we utilize monetary surveys and other related descriptive and quantitative information. With the help of sectoral balance sheets of State Bank of Pakistan, Scheduled Banks, Non-Banking Finance Companies (NBFCs) and Insurance companies, we describe the sectors of the economy to have a broader picture of the economy. To elaborate the linkages between real sector and monetary sector, statistical framework is presented to help understand the mechanism of the utilization of monetary and financial statistics in the analysis of economy. For the discussion on the linkages between real sector and monetary sector, State Bank of Pakistan's monthly data on monetary and financial statistics is analyzed with the help of charts and graphs. For further explanation, few case studies are also discussed in the study.

\subsubsection{Data Sources}

Our database comprises State Bank of Pakistan's monthly data on Monetary and Financial Statistics from July 2006 to February 2009. For analysis, secondary data on inflation and other variables derived from the international publication 'International Financial Statistic (IFS)' and from the different local publications viz. Federal Bureau of Statistics' publications on CPI and publications of State Bank of Pakistan (Banking Statistics, Monthly Bulletin and FSA).

\section{Literature Review}

IMF Country Report (2005) describes the legal framework for statistical activity is broadly adequate, and institutions display a commitment to disseminate macroeconomic statistics, largely through the Internet. Stricter implementation of the law and greater public relations efforts could help address reticence by nonfinancial entities to respond to data requests. There is scope to improve the methodological basis and source data underpinning most datasets, as well as the mix and level of resources in few cases.

Colin Clark's and Martin Wolfe (1995) in the first edition of The Conditions of Economic Progress appeared fifteen years ago, explains that it was greeted with some grudging admiration for the vast amount of labor it represented; it also received a shower of brickbats directed at the procedure Clark employed to show international comparisons of national income.' But in another section of his book, relatively unnoticed, Clark had placed a formidable tool in the hands of students of economic growth and of economic history. 
According to James Tobin (1996) the approach focuses on the capital accounts of economic units, of sectors of the economy, and of the economy as a whole. A model of the capital account of the economy specifies a menu of the assets and debts that appear in portfolios and balance sheets, the factors that determine the demands and supplies of the various assets fall into place as a part, but not the whole, of the menu of assets; and commercial banking system is one sector, but not only one, whose balance sheet behavior must be specified. He further elaborated that, his treatment of the capital account separately from the production and income account of the economy is only a first step, a simplification to be justified by convenience rather than realism. Pakistan's economy (2008) has started to show signs of the beginning to an end of a year long period of mounting difficulties and challenges, yet it has not solved all of its problems. The ensuing vulnerabilities and risks posed complex policy questions that occupied the country during most of 2008. Adnan and Safdar were of the view that the stress on macroeconomic stability was most visible in an unsustainable balance of payments position and the falling value of the rupee. Together with this, escalating CPI inflation, driven both by food and non-food components, and structural problems such as power shortages leading to a gradual decline in real economic activity, aggravated the pressure.

Milton Friedman in the American Economic Review (1996), was of the view that, there is wide agreement about the major goals of economic policy: high employment, stable prices, and rapid growth. There is less agreement that these goals are mutually compatible or, among those who regard them as incompatible, about the terms at which they can and should be substituted for one another. There is least agreement about the role that various instruments of policy can and should play in achieving several goals. The Monetary and Financial Statistics: Compilation Guide (2008) has been designed to accompany the Monetary and Financial Statistics Manual (the Manual), which was published by the International Monetary Fund in 2000. The Manual set forth the broad frameworks for the collection, compilation, and presentation of monetary and financial statistics. The Guide is a lengthier volume that contains more detailed coverage of the classification, economic sectorization, valuation, and recording of various categories of financial assets and liabilities in an economy.

Chan Sau San (2003) discussed the monetary statistics and their application in Macao. He pointed out that regular compilation and release of MFS in Macao began in the early 1980s, following the establishment of the Issuing Institute of Macau (IEM, the predecessor of the Monetary Authority of Macau) in 1980. The reporting system provides the necessary input for the compilation of MFS in Macao. In the early stage, the MFS were released to the public mainly via IEM Annual Reports. Meanwhile, the Macao economy experienced a takeoff in the 1970s and 1980s, driven by the manufacturing sector. Hans and Willeke (2000) discussed the monetary analysis: tools and applications. They referred the proceedings of a seminar in that regard. The aim of the seminar was to obtain an overview of various approaches used to assess monetary developments in major central banks. The seminar involved presentations and discussions by staff members from the ECB, EU national central banks and other G-10 central banks. As it emerged that the papers submitted to the seminar were of more general interest, it was deemed useful to make them available to the public. 
According to Charles Been (2006), monetary and financial statistics make an important contribution to a range of economic policies and analyses. But data collection and publication impose costs on both those who provide information and those who collect and compile statistics. His handbook describes how Cost-Benefit Analysis (CBA) can be used to balance the needs of data users against the burden placed on suppliers. CBA is an established approach in other contexts, particularly for assessing public policy proposals and investment projects, with a range of developed and tested techniques in use.

\section{Analysis}

Statistics and Data Warehouse Department, State Bank of Pakistan is responsible for producing monetary and financial statistics of Pakistan. It takes initiatives not only to produce data but also to inform users about the concepts and methodologies (MFSM 200 Guideline available at http://www.sbp.org.pk/departments/Guidelines.htm) used in collecting, processing and analyzing data, the accuracy of these data and any other feature that affect their quality or "fitness for use".

Today is an era of good governance. The revisions study is being emphasized these days and is recognized as an important tool for transparency and qualitative statistics. Statistics and Data Warehouse Department aims to set and maintain the highest standards of excellence in the compilation and dissemination of efficient statistics. To meet the objective, this department always strives to adopt the best available concepts and methodologies in the contemporary adopted practices internationally. Improvements and switching to these methodologies provides many benefits and opportunities. In terms of asset composition, the share of advances in the total assets of DFIs has improved by 3.21 per cent, while in liabilities composition, the share of borrowings in the total liabilities of DFIs has declined by 11.11 per cent during the quarter. This analysis shows the good management of DFIs in managing their available funds by floating more loans to the customers than to borrow funds from the stakeholders during the period under review. 
Analysis of Non-Banking Financial Sectors

\begin{tabular}{|c|l|c|c|c|c|c|c|}
\hline & & & DFIs & & & NBFCs** & \\
\hline S. No & Description & & & & & Sep-08 & Dec-07 \\
\hline 1 & Advance/Total Assets & & & & & & 27.06 \\
\hline 2 & $\begin{array}{l}\text { Investment in Sec./ Total } \\
\text { Assets }\end{array}$ & & & & & 45.17 & 50.14 \\
\hline 3 & $\begin{array}{l}\text { Non-Fin. Assets/ Total } \\
\text { Assets }\end{array}$ & 3.30 & 3.28 & & & 2.77 & 2.75 \\
\hline 4 & $\begin{array}{l}\text { Borrowings/Liabilities } \\
5\end{array}$ & 34.18 & 38.45 & 37.11 & 14.36 & 12.39 & 12.99 \\
\hline 6 & $\begin{array}{l}\text { Restricted Deposits/ } \\
\text { Liabilities }\end{array}$ & 0.18 & 0.20 & 0.17 & 1.37 & 2.08 & 1.95 \\
\hline 7 & $\begin{array}{l}\text { Other Deposits/ } \\
\text { Liabilities }\end{array}$ & 6.86 & 7.75 & 13.39 & 4.23 & 4.10 & 2.99 \\
\hline 8 & $\begin{array}{l}\text { Bonds \& Debenture/ } \\
\text { Liabilities }\end{array}$ & 2.58 & 2.64 & 4.42 & 5.87 & 3.68 & 2.00 \\
\hline $\begin{array}{l}\text { Shares\& } \\
\text { Liabilities }\end{array}$ & 48.92 & 42.16 & 38.83 & 62.24 & 67.91 & 56.42 \\
\hline $\begin{array}{l}\text { General Reserves/ } \\
\text { Liabilities }\end{array}$ & -1.98 & -5.17 & 3.45 & 11.21 & 10.54 & 7.71 & \\
\hline
\end{tabular}

Souce: State Bank of Pakistan

*Development Financial Institutions

${ }^{* * N}$ Non-Banking Finance Companies

In terms of asset composition, the share of advances in the total assets of NBFCs has improved by 4 per cent, similarly, in liabilities composition, the share of borrowings in the total liabilities of NBFCs has increased by 15.90 per cent during the quarter. This analysis shows the lack of management of NBFCs in handling their available funds by floating fewer loans to the customers as compared to their borrowings from the stakeholders during the period under review.

Historically, the primary focus of the NBFCs has been to strengthen the financial health of their entities, while reducing fragmentation by consolidating and weeding out weak institutions. The declining asset growth among a majority of NBFCs has led to a corresponding deterioration in their relative asset share in performing sector during the year under review. 
Mutual fund is a vehicle for pooling together savings of diverse investors to collectively invest these savings in stocks, bonds and/or money market instruments. Mutual fund has the largest portion in the asset/liabilities composition among all groups of the NBFCs. In terms of asset composition, the share of advances in the total assets, mutual funds comprise 6.29 per cent, while in liabilities composition; the share of borrowings in the total liabilities, mutual funds has 2.18 per cent during the year.

Leasing companies play an important role in capital formation by providing a hybrid form of debt cum investment option. These companies meet the short to medium term funding requirements of business and provide a flexible, tax efficient and economic mode of raising funds. Leasing companies floated 75.51 per cent loans having only 16.64 per cent deposits in December 2008 that is a proof of their management efficiency and better rollover of funds with them.

Investment banks provide strategic advisory services on takeover bids and mergers and acquisition, in addition to mobilizing long-term funds for the equity and bond trading in capital markets. During the quarter under review, their assets reduced by 1.66 per cent while, the share of advances to borrowing has increased by 19.82 per cent in Dec08 . They technically handled their loans despite the deterioration in overall assets during the period under review.

An Asset Management Company is a company that invests its clients' pooled funds into securities that match its declared financial objectives. Asset Management companies provide investors with more diversification and investing options that they would have by themselves. In December 2008, they invested 70.53 per cent of their total assets in market. Their investment to total assets ratio, as compared to borrowing to total liabilities, increased by 142.40 per cent in Dec-08. This depicts the better management of customers' funds by Asset Management companies.

The concept of modarabas was introduced in Pakistan in 1980 through the Modaraba Companies. Since the inception of modaraba companies, various policy initiatives have been introduced for the promotion and growth of this sector in the country. In line with the 17.72 per cent increase in assets, the share of advances to borrowing has also increased by 112.67 per cent during the year. This share of loan distribution by modaraba companies, help modaraba companies to save them from the current financial turmoil. Compilation according to updated definitions and standards, cross comparison, more detailed and bifurcation and information on variables of interest, times series comparisons etc to policymakers, researchers and other stakeholders. In continuation of these efforts, revision study encompassing the changes in Monetary Statistics before and after adopting Monetary and Financial Statistics Manual methodology has been prepared and placed at SBP website at www.sbp.org.pk/ecodata/RSMS.pdf

\subsection{Real Sector}

Real sector refers to the sector in which there are productions of goods and services through combined utilization of raw materials and other production factors such as labor force, land and capital or by means of production process. Market is the determiner of 
what society should produce and through what combination of production factor. There are two major markets in this sector: (1) production faction market, which includes raw material market, labour market, land and capital market. (2) Output market, with the business operators managing the utilization of production factors, and draw materials in order to produce goods and services as exemplified in agricultural and manufacturing productions.

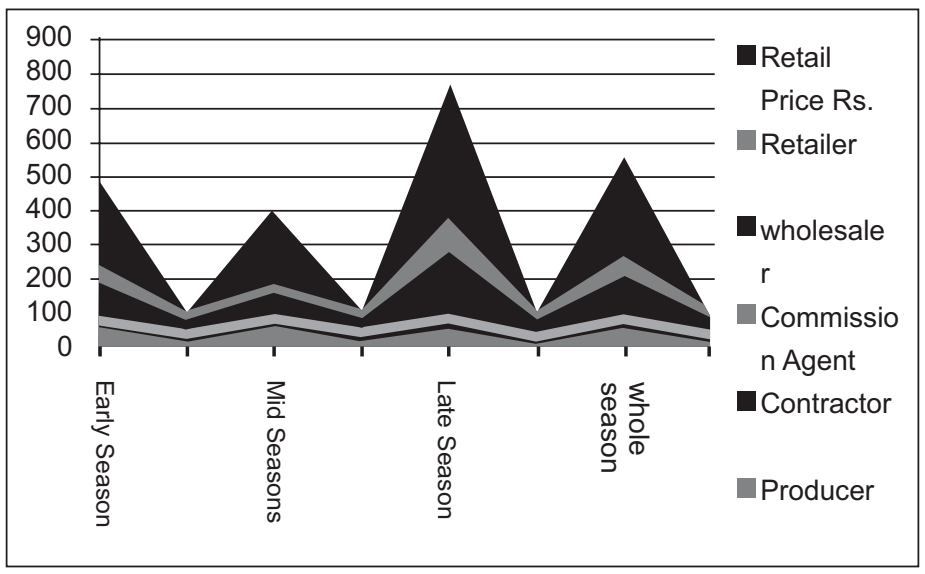

Table: 1 Market Margins of Mango Producers and other Market Intermediaries

\begin{tabular}{|c|c|c|c|c|c|c|c|c|}
\hline \multirow[t]{2}{*}{$\begin{array}{c}\text { Market } \\
\text { Intermediaries }\end{array}$} & \multicolumn{2}{|c|}{$\begin{array}{c}\text { Early } \\
\text { Season }\end{array}$} & \multicolumn{2}{|c|}{$\begin{array}{c}\text { Mid } \\
\text { Season }\end{array}$} & \multicolumn{2}{|c|}{$\begin{array}{c}\text { Late } \\
\text { Season }\end{array}$} & \multicolumn{2}{|c|}{$\begin{array}{l}\text { Whole } \\
\text { Season }\end{array}$} \\
\hline & $\begin{array}{c}\text { Abs. } \\
\text { Cash } \\
\text { Margin } \\
\text { Rs.I } \\
\text { Crate }\end{array}$ & $\begin{array}{c}\% \\
\text { Share } \\
\text { of } \\
\text { Retail } \\
\text { Price }\end{array}$ & $\begin{array}{c}\text { Abs. } \\
\text { Cash } \\
\text { Margin } \\
\text { Rs./ } \\
\text { Crate }\end{array}$ & $\begin{array}{c}\% \\
\text { Share } \\
\text { of } \\
\text { Retail } \\
\text { Price }\end{array}$ & $\begin{array}{c}\text { Abs. } \\
\text { Cash } \\
\text { Margin } \\
\text { Rs.I } \\
\text { Crate }\end{array}$ & $\begin{array}{c}\% \\
\text { Share } \\
\text { of } \\
\text { Retail } \\
\text { Price }\end{array}$ & $\begin{array}{c}\text { Abs. } \\
\text { Cash } \\
\text { Margin } \\
\text { Rs.I } \\
\text { Crate }\end{array}$ & $\begin{array}{c}\% \\
\text { Share } \\
\text { of } \\
\text { Retail } \\
\text { Price }\end{array}$ \\
\hline Producer & 70 & 28 & 70 & 35 & 70 & 18 & 70 & 25 \\
\hline Contractor & 98 & 39 & 73 & 36 & 192 & 49 & 121 & 43 \\
\hline Commission Agent & 15 & 6 & 12 & 6 & 23 & 6 & 17 & 6 \\
\hline Wholesaler & 17 & 7 & 10 & 5 & 15 & 4 & 14 & 5 \\
\hline Retailer & 50 & 20 & 35 & 18 & 90 & 23 & 58 & 21 \\
\hline Retail Price Rs. & \multicolumn{2}{|c|}{250} & \multicolumn{2}{|c|}{200} & \multicolumn{2}{|c|}{390} & \multicolumn{2}{|c|}{280} \\
\hline
\end{tabular}

Source: Survey Data, Khushk \& SImith 1993

Mango consumers are convinced by its good flavor, delicacy, and nutrient value, and domestic demand is strong. Mango producers tend to increase production due to the sustained and favourable income generated. 
Table: $\mathbf{2}$ Logistic Regression Model for Reliability of Purchased Groundwater

\begin{tabular}{|l|c|c|c|}
\hline \multicolumn{1}{|c|}{ Independent Variables } & Coefficient & T-Ratio & Wald Statistics \\
\hline Electric & -2.189 & -2.934 & 8.617 \\
\hline Diameter & 1.267 & 2.368 & 5.587 \\
\hline Depth & -0.26 & -1.245 & 4.553 \\
\hline Landown & 0.072 & 1.986 & 3.949 \\
\hline Age & 0.045 & 1.844 & 3.398 \\
\hline Relative & 0.855 & 0.866 & 0.750 \\
\hline Landlord & 10.613 & 0.435 & 0.189 \\
\hline
\end{tabular}

Findings indicate that larger and older farmers are more likely to own tube wells, and hence control groundwater supplies. Groundwater markets improve the access to groundwater for small farmers, landless tenants, and younger households. Although groundwater legally belongs to the owners of the overlying land, in practice it is owned by the owners of the tube wells. However, well owners do not charge full scarcity value for the water.

\subsection{Monetary Sector}

The Monetary system consists of the Central Bank and all institutions that create money, mainly commercial banks. Accordingly, data on monetary aggregates and other measurable indicators of the measures the Central Bank, the monetary authority of the country, has taken under its monetary management, are provided under monetary sector.

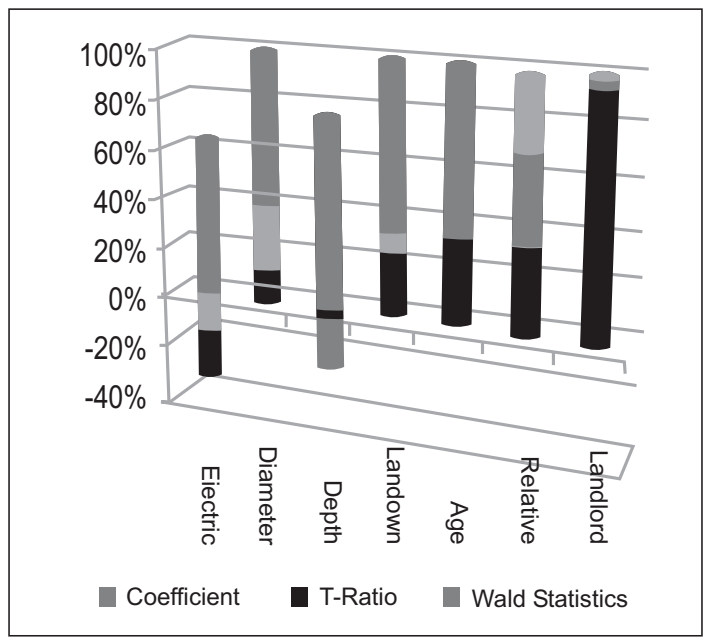


Table 3: Quarterly Broad Money Liabilities

\begin{tabular}{|l|l|l|l|l|l|l|l|l|l|l|l|l|l|}
\hline & \multicolumn{3}{|c|}{2006} & \multicolumn{5}{c|}{2007} & \multicolumn{2}{|c|}{2008} & \multicolumn{2}{c|}{2009} \\
\hline $\begin{array}{l}\text { Billio } \\
\text { n Rs. }\end{array}$ & Jun & Sep & Dec & Mar & Jun & Sep & Dec & Mar & Jun & Sep & Dec & Jan & Feb \\
\hline M2 & $\begin{array}{l}3,40 \\
8\end{array}$ & $\begin{array}{l}3,41 \\
3\end{array}$ & $\begin{array}{l}3,66 \\
5\end{array}$ & $\begin{array}{l}3,77 \\
5\end{array}$ & $\begin{array}{l}4,05 \\
3\end{array}$ & $\begin{array}{l}4,11 \\
5\end{array}$ & $\begin{array}{l}4,38 \\
8\end{array}$ & $\begin{array}{l}4,39 \\
8\end{array}$ & $\begin{array}{l}4,67 \\
1\end{array}$ & $\begin{array}{l}4,51 \\
9\end{array}$ & $\begin{array}{l}4,62 \\
9\end{array}$ & $\begin{array}{l}4,57 \\
0\end{array}$ & $\begin{array}{l}4,61 \\
7\end{array}$ \\
\hline $\begin{array}{l}\text { YoY } \\
\text { grow } \\
\text { grow } \\
\text { th }\end{array}$ & & & 18.9 & 19.0 & 15.1 & 16.5 & 12.0 & 9.8 & 5.5 & 6.2 & 6.0 \\
\hline
\end{tabular}

Source: State Bank of Pakistan

Broad money (M2) is used as the intermediate target for monetary policy execution in Pakistan because it has linkages to the real, fiscal, and external sectors of the economy. For instance, external sector developments are reflected in changes in the net foreign assets (NFA) of the banking system while government borrowings from the banking system are indicative of the fiscal position. These interrelationships are captured in the monetary policy framework. Moreover, data on monetary aggregates are available relatively quickly. Thus, paying attention to monetary aggregates allows policy makers to form an informed view about the economy and take timely decisions regarding its policy stance.

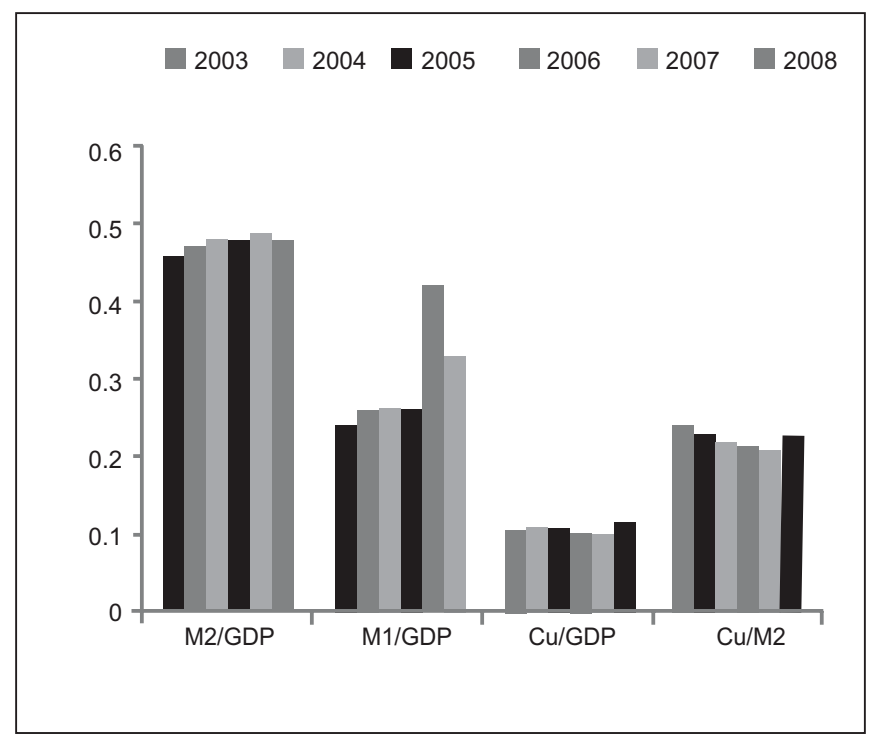

The level of financial deepening, in Pakistan, as measured by $\mathrm{Cu} / \mathrm{M} 2+, \mathrm{M} 1 / \mathrm{GDP}$, M2/GDP and Cu/GDP improved between 2003 and 2008. Table 1 shows that M2/GDP ratios increased from 0.46 in 2003 to 0.48 in 2008. Similarly, the currency/GDP ratio improved by 3.7 percentage points over the same period, while the currency ratio (Currency/M2) declined by 4.2 percentage points for the same period. In Pakistan, 
currency accounts for a greater proportion of transactions. Thus, the persistent decline in the currency ratio, since the year 2003, signals an improvement in the financial depth of the economy. The decline in cash holdings in recent times can be attributed to the increase in the use of electronic cards within the economy.

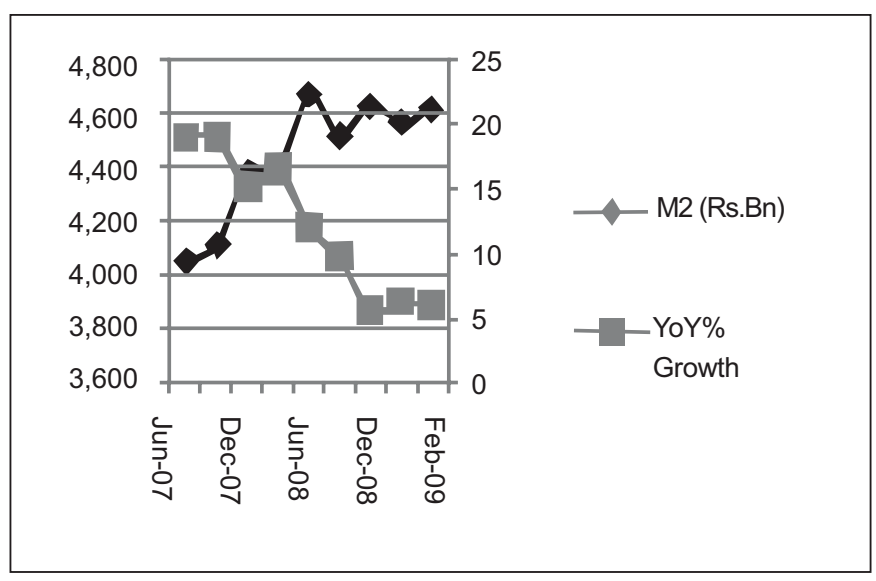

Table: 4 Financial Deepening in Pakistan (Billion Rupees)

\begin{tabular}{|c|c|c|c|c|c|c|c|c|}
\hline $\begin{array}{l}\text { Year- } \\
\text { end }\end{array}$ & M2 & M1 & $\begin{array}{c}\text { Currency } \\
\text { Cu }\end{array}$ & GDP & M2/GDP & M1/GDP & Cu/GDP & Cu/M2 \\
\hline $\mathbf{2 0 0 3}$ & $\begin{array}{c}207 \\
9\end{array}$ & 1106 & 494.6 & 4534 & 0.46 & 0.24 & 0.109 & 0.24 \\
\hline $\mathbf{2 0 0 4}$ & $\begin{array}{c}248 \\
6\end{array}$ & 1370 & 578.1 & 5251 & 0.47 & 0.26 & 0.110 & 0.23 \\
\hline $\mathbf{2 0 0 5}$ & $\begin{array}{c}296 \\
0\end{array}$ & 1619 & 665.9 & 6123 & 0.48 & 0.26 & 0.109 & 0.22 \\
\hline $\mathbf{2 0 0 6}$ & $\begin{array}{c}340 \\
7\end{array}$ & 1831 & 740.4 & 7159 & 0.48 & 0.26 & 0.103 & 0.22 \\
\hline $\mathbf{2 0 0 7}$ & $\begin{array}{c}406 \\
5\end{array}$ & 3491 & 840.2 & 8259 & 0.49 & 0.42 & 0.102 & 0.21 \\
\hline $\mathbf{2 0 0 8}$ & $\begin{array}{c}479 \\
2\end{array}$ & 3310 & 1124.0 & 9906 & 0.48 & 0.33 & 0.113 & 0.23 \\
\hline
\end{tabular}

Source: Annual Report, State Bank of Pakistan 


\section{CASE STUDY-1}

\section{Financial Sector Development, Savings Mobilization and Poverty Reduction in Ghana, December 2005}

The paper primarily investigates the interrelationship between financial sectors development and poverty reduction in Ghana. This is done using time-series data from the World Development Indicators from 1970-2001. The main findings are, first, that even though financial sector development does not Granger-cause savings mobilization in Ghana, it induces poverty reduction; and second, that savings do Granger-cause poverty reduction in Ghana. Also, the effect of financial sector development on poverty reduction is positive but insignificant. This is due to the fact that financial intermediaries in Ghana have not adequately channeled savings to the pro-poor sectors of the economy because of government deficit financing, high default rate, lack of collateral and lack of proper business proposals.

\section{CASE STUDY-2}

\section{Monetary Conditions Index for Pakistan, SBP Working Paper Series By Zulfiqar Hyder and Muhammad Mazhar Khan}

The paper discusses how changes in interest rate and exchange rate, through Monetary Conditions Index $(\mathrm{MCl})$, are used for assessing the overall monetary policy stance. The weights for construction of $\mathrm{MCl}$ are derived using the Johansen's cointegration techniques. The constructed $\mathrm{MCl}$ indicates that Pakistan has eight tight and six soft periods of monetary stance during March 1991 to April 2006. The Monetary Conditions Index at time $t, t \mathrm{MCl}$, is defined as the weighted sum of changes in the exchange rate ( $E R$ in logs) and in the interest rate (INTR in levels) from their levels in a chosen base year. The formula for $\mathrm{MCl}$ is as follows:

$$
M C I=w I N T R-I N T R+w E R-E R
$$

Where t INTR and t ER are interest rate (call money rate/6-month T-bill rate) and exchange rate at time $t$, respectively. $b$ INTR and $b$ ER are interest rate and exchange rate at a given base year. The most important factor is weights, $w$, as the value of these weights provides useful information regarding the relative importance of interest rates and exchange rates in influencing the ultimate goal of either output or inflation.

\section{CASE STUDY -3}

\section{Estimating Output Gap for Pakistan Economy: Structural and Statistical Approaches by S. Adnan, H. A. S. Bukhari and Safdar Ullah Khan}

The objective of this study is to estimate potential output vis-à-vis output gap for Pakistan's economy. The linear trend method is the simplest way to estimate the output gap and potential output. 


$$
Y t=\alpha^{\wedge} 0+\alpha^{\wedge} 1 T R E N D \quad t=1,2 \ldots
$$

Where $Y t$ is potential output and $0 \alpha^{\wedge}$ and $1 \alpha^{\wedge}$ are the estimated coefficients from the regression of the actual output (Yt) on time trend variable (TREND), and output gap (YGAPt) is obtained using:

\section{Conclusion and Recommendations}

Statistics and Data Warehouse Department, State Bank of Pakistan is responsible for producing monetary and financial statistics of Pakistan. It takes initiatives not only to produce data but also to inform users about the concepts and methodologies used in collecting, processing and analyzing data, the accuracy of these data and any other feature that affect their quality or "fitness for use".

The paper introduced the application techniques of Monetary and Financial Statistics (MFS) in Pakistan under a theoretically sound framework. A thorough understanding of macroeconomic developments inevitably requires the consideration of monetary elements in view of the intrinsic link between the real sector and the monetary sector. The study explained the unique linkages of the monetary sector to the real sector economy with the help of few examples and relevant case studies.

It is recommended that further work on the same thrust can be helpful with the development of regression models to highlight the linkages of these sectors in the analysis of an economy. Awareness of the public/researchers to the treasure of data available on web-sites of the institutions can be beneficial not only for the stakeholders but also for the institutions in improving their day to day operations by two-way sharing of information. 


\section{References}

Chan Sau San (2003), "Monetary statistics and their applications-the Macao example", Monetary Authority, Journal of Macao economy, No. 15, pp 20-32.

Charles Been, (2006) "Cost-benefit analysis of monetary and financial statistics', Bank of England, A practical guide R\&D Team, MFSD, Bank of England.

Colin Clark's and Martin Wolfe (1995), "The Concept of Economic Sectors", The Quarterly Journal of Economics, MIT Press Vol. 69, No. 3 pp. 402-420.

Hans-Joachim Klöckers and Caroline Willeke (November 2000), "Monetary Analysis: Tools and Applications", ECB's Directorate Monetary Policy.

International Monetary Fund, (2008), Monetary and financial statistics: compilation guide, Washington.

IMF Country Report No. 05/208 (June 2005), "Guatemala: Report on the Observance of Standards and Codes", International Monetary Fund, Publication Services 700, N.W. Washington.

James Tobin (Feb., 1996), "A General Equilibrium Approach to Monetary Theory", Journal of Money,

Credit and Banking, Vol. 1, No. 1 pp. 15-29.

Milton Friedman (1996), "The American Economic Review", Vol. LVIII No. 1.

S. Adnan H. A. S. Bukhari and Safdar Ullah Khan, (November 2008), "Estimating Output Gap for Pakistan Economy: Structural and Statistical Approaches", SBP Research Bulletin, Volume 4, Number 1 pp 1-30. 